\title{
Beta-D-Glucan in Patients with Haematological Malignancies
}

\author{
Malgorzata Mikulska ${ }^{1,2, *(1)}$, Elisa Balletto ${ }^{2}$, Elio Castagnola ${ }^{3}$ and Alessandra Mularoni ${ }^{4}$ \\ 1 Division of Infectious Diseases, Department of Health Sciences (DISSAL), University of Genoa, \\ 16132 Genoa, Italy \\ 2 Division of Infectious Diseases, IRCCS Ospedale Policlinico San Martino, 16132 Genoa, Italy; \\ elisa.balletto@hsanmartino.it \\ 3 Infectious Diseases Unit, Department of Pediatrics, Istituto Giannina Gaslini, 16147 Genova, Italy; \\ eliocastagnola@gaslini.org \\ 4 IRCCS-ISMETT (Istituto Mediterraneo per i Trapianti e Terapie ad Alta Specializzazione), \\ 90127 Palermo, Italy; amularoni@ismett.edu \\ * Correspondence: m.mikulska@unige.it; Tel.: +39-010-555-4649
}

Citation: Mikulska, M.; Balletto, E.; Castagnola, E.; Mularoni, A. Beta-D-Glucan in Patients with Haematological Malignancies. J. Fungi 2021, 7, 1046. https:// doi.org/10.3390/jof7121046

Academic Editor: Marcio Nucci

Received: 9 November 2021

Accepted: 2 December 2021

Published: 7 December 2021

Publisher's Note: MDPI stays neutral with regard to jurisdictional claims in published maps and institutional affiliations.

Copyright: (c) 2021 by the authors. Licensee MDPI, Basel, Switzerland. This article is an open access article distributed under the terms and conditions of the Creative Commons Attribution (CC BY) license (https:// creativecommons.org/licenses/by/ $4.0 /)$.

\begin{abstract}
D-glucan (BDG) is an almost panfungal marker (absent in zygomycetes and most cryptococci), which can be successfully used in screening and diagnostic testing in patients with haematological malignancies if its advantages and limitations are known. The aim of this review is to report the data, particularly from the last 5 years, on the use of BDG in haematological population. Published data report mainly on the performance of the Fungitell ${ }^{\mathrm{TM}}$ assay, although several others are currently available, and they vary in method and cut-off of positivity. The sensitivity of BDG for invasive fungal disease (IFD) in haematology patients seems lower than in other populations, possibly because of the type of IFD (lower sensitivity was found in case of aspergillosis compared to candidiasis and pneumocystosis) or the use of prophylaxis. The specificity of the test can be improved by using two consecutive positive assays and avoiding testing in the case of the concomitant presence of factors associated with false positive results. BDG should be used in combination with clinical assessment and other diagnostic tests, both radiological and mycological, to provide maximum information. Good performance of BDG in cerebrospinal fluid (CSF) has been reported. BDG is a useful diagnostic method in haematology patients, particularly for pneumocystosis or initial diagnosis of invasive fungal infections.
\end{abstract}

Keywords: glucan; invasive fungal infections; neutropenia; aspergillosis; pneumocystosis; cerebral infection

\section{Introduction}

Invasive fungal infections (IFDs) continue to be an important infectious complication in patients with haematological malignancy (HM) and those undergoing stem cell transplantation (HSCT). Early diagnosis and treatment can contribute to reducing the mortality, and over the past 20 years, significant efforts have been made to establish reliable diagnostic methods for IFD in the immunocompromised [1]. Together with early radiological evaluation, mycological assays, both culture-based and non-cultural have allowed prompt diagnosis of IFD in this setting.

Among non-culture-based assays, galactomannan (GM) detection in serum or in bronchoalveolar lavage (BAL) is the mainstay of the diagnosis of invasive aspergillosis. Although its performance is not perfect, it is the most important fungal marker in patients with HM, since aspergillosis is the most frequent IFD, while Candida infections are rather rare due to the common use of azole prophylaxis.

Another fungal marker is (1-3)-beta-D-glucan (BDG), which can be detected in serum for the diagnosis of not only aspergillosis but also other IFDs. The usefulness of BDG in the haematology setting has been extensively studied, with certain differences emerging for this population. The epidemiology of IFD is characterized by the predominance of invasive aspergillosis (IA) and a limited number of cases of invasive candidiasis (IC) as 
compared to other populations that are at risk for IC, such as intensive care unit (ICU) critically ill patients [2]. Pneumocystis jirovecii pneumonia (PJP) is another important IFD in the haematology population, for which BDG has been shown useful.

However, the availability of BDG is much more limited than that of GM, as shown in a recent survey on the treatment of IA in haematology patents in Europe [3]. While GM was available in serum and bronchoalveolar lavage in most of the 112 included centres $(95 \%$ and $87 \%$, respectively), BDG was available only in $21 \%$. Thus, the practical knowledge of this test, including its strengths and limitations in the haematology setting, is fundamental for deciding whether to add it to the diagnostic armamentarium in single haematology centres.

BDG can be a valuable contribution to the diagnosis and management of IFDs in the haematology setting, provided clinicians have thorough knowledge of the advantages and limitations of the use of the BDG test in this specific population, which are different from other patient populations such as critically ill or surgical patients.

The aim of this review was to provide an update on recent data on the utility of BDG in the haematology setting.

Therefore, an updated MEDLINE/PubMed search (search terms: glucan AND [hematolog* OR haematolog* OR neutropeni*]) was performed on 1 October 2021, limited to the years 2016-2021. Previous relevant data were also considered.

\section{Description of BDG Assays}

The BDG test is based on the detection of the polysaccharide (1,3)-ßB-D-glucan, which is a component of the cell wall of many pathogenic fungi, except for Mucorales and most strains of Cryptococcus [4,5]. Since BDG can be positive in numerous different IFDs, other diagnostic methods, both radiological and mycological, are necessary to attribute a positive BDG result to a specific IFD.

While the first BDG assay was introduced in the 1980s in Japan, other assays were developed and are currently approved by U.S. Food and Drug Administration or carry the Conformite Europeenne (CE) marking, with the Fungitell assay (Associated Cape-Cod, Inc., East Falmouth, MA, USA) being the first one approved by the US FDA in 2004 and then marked $\mathrm{CE}$, and most comparisons performed between Fungitell and Wako assays (Wako Pure Chemical Industries, Tokyo, Japan) [6,7]. These assays have different methods for BDG detection and cut-off values for positivity, which include, in some assays, the indeterminate zone. The detailed characteristics of the assays are outlined in Table 1 [7-11].

Table 1. Comparison of characteristics of different beta-D-glucan test assays.

\begin{tabular}{|c|c|c|c|c|c|c|c|c|}
\hline Test Assay & Availability & Producer & Method & Cut-Off Value & $\begin{array}{c}\text { Overall } \\
\text { Sensitivity }\end{array}$ & $\begin{array}{c}\text { Overall } \\
\text { Specificity }\end{array}$ & Comments & Reference \\
\hline Fungitell & $\begin{array}{c}\text { Europe, } \\
\text { US }\end{array}$ & $\begin{array}{l}\text { Associates } \\
\text { of Cape } \\
\text { Cod, } \\
\text { Falmouth, } \\
\text { MA, USA }\end{array}$ & Colorimetric & $\begin{array}{c}\text { Intermediate } \\
60-79 \mathrm{pg} / \mathrm{mL} \\
\text { Positive > } \\
80 \mathrm{pg} / \mathrm{mL}\end{array}$ & $27-100 \%$ & $0-100 \%$ & $\begin{array}{l}\text { BDG detection by } \\
\text { Fungitell is part of } \\
\text { EORTC/MSG criteria } \\
\text { (positive serum BDG } \\
\text { in combination with } \\
\text { host factor and } \\
\text { clinical criterion) for } \\
\text { probable invasive } \\
\text { candidiasis or PJP. }\end{array}$ & [7-9] \\
\hline $\begin{array}{l}\text { Fungitell } \\
\text { STAT }\end{array}$ & $\begin{array}{c}\text { Europe, } \\
\text { US }\end{array}$ & $\begin{array}{l}\text { Associates } \\
\text { of Cape } \\
\text { Cod, } \\
\text { Falmouth, } \\
\text { MA, USA }\end{array}$ & & $\begin{array}{c}\text { Indeterminate } \\
0.75-1.1 \\
\text { Positive } \geq 1.2\end{array}$ & ND & ND & $\begin{array}{l}\text { New rapid test that } \\
\text { can be run on one or } \\
\text { more patient } \\
\text { specimens (single } \\
\text { sample testing), but } \\
\text { initial clinical } \\
\text { validation reported } \\
98-99 \% \text { concordance } \\
\text { with indeterminate } \\
\text { results excluded and } \\
74-91 \% \text { if included. }\end{array}$ & [11] \\
\hline
\end{tabular}


Table 1. Cont.

\begin{tabular}{|c|c|c|c|c|c|c|c|c|}
\hline $\begin{array}{c}\text { Test } \\
\text { Assay }\end{array}$ & Availability & Producer & Method & Cut-Off Value & $\begin{array}{c}\text { Overall } \\
\text { Sensitivity }\end{array}$ & $\begin{array}{c}\text { Overall } \\
\text { Specificity }\end{array}$ & Comments & Reference \\
\hline Glucatell & $\begin{array}{c}\text { Europe, } \\
\text { US }\end{array}$ & $\begin{array}{l}\text { Associates } \\
\text { of Cape } \\
\text { Cod, Fal- } \\
\text { mouth, } \\
\text { MA, USA }\end{array}$ & Colorimetric & $80 \mathrm{pg} / \mathrm{mL}$ & $50-92 \%$ & $41-94 \%$ & $\begin{array}{l}\text { The Glucatell test } \\
\text { differs from the } \\
\text { Fungitell test in } \\
\text { that the Glucatell } \\
\text { reagent is } \\
\text { processed to } \\
\text { eliminate Factor } \\
\text { C. This makes } \\
\text { the Glucatell test } \\
\text { more specific for } \\
\text { BDG linkages. } \\
\text { The Glucatell } \\
\text { reagent does not } \\
\text { react to other } \\
\text { polysaccharides, } \\
\text { including } \\
\text { beta-glucans } \\
\text { with other } \\
\text { glycosidic } \\
\text { linkages. }\end{array}$ & {$[7,9]$} \\
\hline $\begin{array}{c}\text { Wako } \\
\text { Wako-EU }\end{array}$ & $\begin{array}{l}\text { Asia, } \\
\text { Europe }\end{array}$ & $\begin{array}{l}\text { Wako } \\
\text { Pure } \\
\text { Chemical } \\
\text { Indus- } \\
\text { tries, } \\
\text { Osaka, } \\
\text { Japan }\end{array}$ & $\begin{array}{l}\text { Turbidimetric } \\
\text { method }\end{array}$ & $11 \mathrm{pg} / \mathrm{mL}$ & $50-86 \%$ & $89-100 \%$ & & {$[7-10]$} \\
\hline $\begin{array}{c}\text { Fungitec } \\
\text { G test ES } \\
\text { Fungitec } \\
\text { G test } \\
\text { MKII }\end{array}$ & $\begin{array}{c}\text { Europe, } \\
\text { US }\end{array}$ & $\begin{array}{c}\text { Seikagaku } \\
\text { Kogyo } \\
\text { Corpora- } \\
\text { tion, } \\
\text { Tokyo, } \\
\text { Japan } \\
\text { Sub- } \\
\text { sidiary } \\
\text { Asso- } \\
\text { ciates of } \\
\text { Cape } \\
\text { Cod, Fal- } \\
\text { mouth, } \\
\text { MA, USA }\end{array}$ & $\begin{array}{l}\text { Colorimetric } \\
\text { method }\end{array}$ & $20 \mathrm{pg} / \mathrm{mL}$ & $67-88 \%$ & $60-85 \%$ & & {$[7,9]$} \\
\hline $\begin{array}{l}\text { Dynamiker } \\
\text { Fungus }\end{array}$ & $\begin{array}{c}\text { Some } \\
\text { European } \\
\text { countries } \\
\text { and } \\
\text { North } \\
\text { Africa }\end{array}$ & $\begin{array}{c}\text { Dynamiker } \\
\text { Biotech- } \\
\text { nology } \\
\text { Ltd., } \\
\text { Tianjin, } \\
\text { China }\end{array}$ & $\begin{array}{l}\text { Turbidimetric } \\
\text { method }\end{array}$ & $95 \mathrm{pg} / \mathrm{mL}$ & $64-81 \%$ & $78-80 \%$ & & {$[7,9]$} \\
\hline
\end{tabular}

ND, no data.

\section{Recent Data on Optimized Thresholds}

Recently, a prospective comparison of Fungitell and Wako resulted in a proposal of optimized thresholds (higher and lower than the manufacturer's recommendations, respectively) [12]. The study was performed in 171 patients, mainly with $\mathrm{HM}(62 \%)$, who had experienced 175 episodes of suspected IFD, with the final diagnosis of 23 infections due to BDG-producing fungi (including 12 cases of PJP). For optimized thresholds of 
$120 \mathrm{pg} / \mathrm{mL}$ for Fungitell and $4 \mathrm{pg} / \mathrm{mL}$ for Wako, the sensitivity and specificity were $82 \%$ and $95 \%$ for Fungitell and $82 \%$ and $95 \%$ for Wako, compared to a Wako sensitivity of $50 \%$ with the manufacturer's positivity threshold of $11 \mathrm{pg} / \mathrm{mL}$ and a specificity that remained similar [12].

In a recent retrospective analysis of serum samples from patients with and without PJP based on clinical and radiological characteristics and polymerase chain reaction (PCR) in BAL, the performance of Fungitell and Wako assays was compared [13]. At the manufacturer's recommended cut-offs $(80 \mathrm{pg} / \mathrm{mL}$ and $11 \mathrm{pg} / \mathrm{mL}$, respectively), the Wako assay was found significantly more specific $(0.98$ vs. 0.87$)$ and the Fungitell assay more sensitive ( 0.78 vs. 0.85 ), with similar overall performance. At a cut-off of $3.616 \mathrm{pg} / \mathrm{mL}$, the Wako assay had similar sensitivity to the Fungitell assay ( 0.88 at a cut-off of $\geq 60 \mathrm{pg} / \mathrm{mL}$ ), but its specificity was significantly higher (0.89 vs. 0.82 ) [13].

In conclusion, a higher cut-off for the Fungitell and lower for the Wako assay might result in improved overall performance in patients with HM. However, reducing the sensitivity of Fungitell, which is the advantage of this assay, might be counterproductive in the haematology setting, especially in the diagnosis of IPA or pre-emptive antifungal therapy for febrile neutropenia, when sensitivity is crucial [14]. In these cases, lower specificity of standard cut-offs might be preferable, and repeated sampling might rule out false positive results.

\section{False Positive and False Negative Results of BDG Assay}

All the reported causes of false positive and false negative results of BDG are reported in Table 2 [2,15-27]. Interestingly, recently reported sporadic causes of false positive BDG results include intake of seaweed in a HSCT recipient with grade II skin and gastrointestinal graft versus host disease (GvHD) (with a maximum BDG value of $229 \mathrm{pg} / \mathrm{mL}$ ) [28] and continuous administration of penicillin $\mathrm{G}$ (with a maximum BDG value of $81 \mathrm{pg} / \mathrm{mL}$ ) [29].

Table 2. Potential causes of false positive and false negative results of serum BDG; underlined cases are considered as clinically important and potentially frequent [2,15-27].

\begin{tabular}{|c|c|c|}
\hline FALSE POSITIVES & Mechanism & Comments \\
\hline \multicolumn{3}{|l|}{ Iatrogenic contamination } \\
\hline Haemodialysis & $\begin{array}{l}\text { Use of regenerated cellulose } \\
\text { dialysis membrane }\end{array}$ & $\begin{array}{l}\text { Modern dialysis membranes (non-BDG-leaching synthetic } \\
\text { membranes) no longer release BDG, and BDG was highly specific for } \\
\text { the diagnosis of IFD in the serum of patients receiving haemodialysis } \\
\text { in a recent study [27]. }\end{array}$ \\
\hline $\begin{array}{l}\text { Blood and blood derivates such as } \\
\text { immunoglobulins and albumin }\end{array}$ & $\begin{array}{l}\text { Cellulosic depth filters are } \\
\text { generally mixtures of cellulose } \\
\text { and diatomaceous earth and are } \\
\text { used to provide initial clarification } \\
\text { of blood plasma. Process solutions } \\
\text { may also contain BDG and } \\
\text { introduce contamination. }\end{array}$ & $\begin{array}{l}\text { The risk of false positivity after receiving blood or blood components } \\
\text { seems dependent on the product's concentrations of BDG and is not } \\
\text { constant (for example, never observed in our hospital), while } \\
\text { immunoglobulin preparations almost invariably contain BDG [17]. } \\
\text { These high titres usually decline rather quickly, and such responses } \\
\text { support suspicion of iatrogenic contamination. } \\
\text { The depth filters flush strategy was developed to control beta-glucan } \\
\text { leaching into the product pool [23]. }\end{array}$ \\
\hline $\begin{array}{l}\text { Cellulose containing } \\
\text { gauzes/surgical sponges }\end{array}$ & & $\begin{array}{l}\text { The release of BDG from surgery gauzes is temporary and depends } \\
\text { on the type of gauze used [25]. }\end{array}$ \\
\hline $\begin{array}{l}\text { Non-glucan-free } \\
\text { laboratory equipment }\end{array}$ & & $\begin{array}{c}\text { Currently unlikely, since glucan-free laboratory } \\
\text { equipment is available. }\end{array}$ \\
\hline $\begin{array}{l}\text { Beta-lactam antibiotics (e.g., } \\
\text { ampicillin-sulbactam, } \\
\text { amoxicillin-clavulanate) }\end{array}$ & $\begin{array}{l}\text { BDG may be present in the } \\
\text { original source material itself, } \\
\text { such as products made by fungal } \\
\text { fermentation, in excipients added } \\
\text { to the formulation, from media } \\
\text { used in microbial or cell culture, } \\
\text { or from process equipment, } \\
\text { materials, and solutions. }\end{array}$ & $\begin{array}{l}\text { Possible; however, the high level of dilution generated upon injection } \\
\text { of relatively low volumes of antibiotic make this unlikely. Further, the } \\
\text { high negative predictive value for IFD observed for patients receiving } \\
\text { a vast array of antibiotics suggests that this is } \\
\text { not a significant problem [20]. }\end{array}$ \\
\hline Bacteriemia & $\begin{array}{l}\text { Translocation as a consequence of } \\
\text { ischemic damage to the intestinal } \\
\text { barrier due to septic shock }\end{array}$ & $\begin{array}{l}\text { Some experiences suggest that bacteraemia is a very rare } \\
\text { source of false positivity [21]. }\end{array}$ \\
\hline
\end{tabular}


Table 2. Cont.

\begin{tabular}{|c|c|c|}
\hline FALSE POSITIVES & Mechanism & Comments \\
\hline \multicolumn{3}{|l|}{ Intestinal translocation } \\
\hline$\underline{\text { Severe mucositis }}$ & $\begin{array}{l}\text { Possible translocation of fungal } \\
\text { antigens through the intestinal } \\
\text { mucosa damaged by } \\
\text { chemotherapy }\end{array}$ & $\begin{array}{l}\text { Whether or not this might truly affect specificity of BDG in adult } \\
\text { hematologic patients remains controversial, but should be considered } \\
\text { in patients with intestinal GvHD or severe mucositis [2]. }\end{array}$ \\
\hline Major abdominal surgery & $\begin{array}{c}\text { Translocation as a consequence of } \\
\text { loss of integrity } \\
\text { of the intestinal wall }\end{array}$ & Rare in haematology. \\
\hline Gut ischemia & $\begin{array}{l}\text { Translocation as a consequence of } \\
\text { is chemic damage }\end{array}$ & \\
\hline Burns & Large surface area burns & $\begin{array}{l}\text { Validation of alternative cut-offs in specific clinical contexts known to } \\
\text { contribute to elevated BDG titre may provide the solution to } \\
\text { specificity issues [24]. } \\
\text { Unknown if applicable also to severe skin acute GvHD. }\end{array}$ \\
\hline Chronic kidney disease & Uremia's metabolic toxicity & \\
\hline Enterococcus spp. bacteremia & $\begin{array}{l}\text { Protease-producing } \\
\text { intestinal enterococci }\end{array}$ & \\
\hline \multicolumn{3}{|l|}{ Hepatic function } \\
\hline End-stage liver disease & Reduced clearance & \\
\hline \multicolumn{3}{|l|}{ Bacterial infections } \\
\hline Nocardia spp. infection & & $\begin{array}{l}\text { Although rare, needs to be considered in differential diagnosis in case } \\
\text { of compatible clinical presentation (pulmonary, cerebral) [15]. }\end{array}$ \\
\hline Streptococcus pneumoniae Type 37 & $\begin{array}{l}\text { Producing a BDG with a } \\
(1 \rightarrow 3)-\beta \text {-backbone }[15]\end{array}$ & \\
\hline Pseudomonas spp. & $\begin{array}{l}\text { Producing }(1 \rightarrow 2) \text { - } \beta \text {-linked } \\
\text { glucan sequences [15] }\end{array}$ & \\
\hline \multicolumn{3}{|l|}{ Interference } \\
\hline Pegylated asparaginase & $\begin{array}{l}\text { Drug-related alterations in heme } \\
\text { metabolism, which in turn } \\
\text { interfere with measurement of } \\
\text { BDG in serum [2] }\end{array}$ & \\
\hline Haemolysis & Interference with test procedure. & Possible interference, particularly for colorimetric assays [22]. \\
\hline \multicolumn{3}{|l|}{ FALSE NEGATIVES } \\
\hline Antifungal prophylaxis and therapy & Low pre-test probability of IFI & $\begin{array}{l}\text { Lower median BDG values were reported in breakthrough IFI } \\
\text { episodes [16]. } \\
\text { BDG should be used to exclude rather than for diagnosis in these } \\
\text { patients [18]. }\end{array}$ \\
\hline $\begin{array}{l}\text { Sanctuary sites or poorly } \\
\text { vascularized sites of infection }\end{array}$ & BDG not released into blood & \\
\hline$\frac{\text { Candida parapsilosis }}{\text { or Candida auris }}$ & $\begin{array}{l}\text { Lower content of BDG component } \\
\text { in fungal wall }\end{array}$ & Lower levels of BDG reported $[19,26]$. \\
\hline Hyperbilirubinemia & Interference with test procedure & Possible interference, particularly for colorimetric assays [22]. \\
\hline
\end{tabular}

\section{BDG in Screening in Patients with Haematological Malignancies}

Numerous studies have reported experience with BDG screening in haematological populations, some of them reporting better performance if used with other markers, such as GM [30]; however, the results varied based on the prevalence and type of IFD in the screened population and the study design (case-control vs. cohort studies): in the case control studies, the group of "grey area" patients in whom IFD could not be confirmed or excluded were not included.

Indeed, in a large, recent study of BDG in screening and diagnosis in haematologic patients receiving anti-mould prophylaxis, i.e., with low prevalence of IFD, among the 203 episodes included, 62 were classified as non-evaluable [18]. In that study, eight episodes of proven/probable IFD were diagnosed (5.7\%), and the sensitivity, specificity, positive 
predictive value, and negative predictive value were $50.0 \%, 84.2 \%, 16.1 \%$, and $96.5 \%$, respectively. Despite high NPV (negative predictive value), with a sensitivity of $50 \%$, the use of BDG to exclude IFD does not seem appropriate outside the setting with a very low pre-test probability.

Therefore, the meta-analysis performed for the European Conference on Infections in Leukemia (ECIL) and published in 2012 is very helpful, as it attempted to limit this heterogeneity of the studies by restricting the analysis to prospective cohort studies (in 5/6 of which BDG was used for screening, and in 1/6 for targeted diagnosis) in 1771 haematology patients [31]. For the diagnosis of proven or probable IFD, the positive test sensitivity and specificity were $70 \%$ (95\% CI 47-86) and 91\% (95\% CI 83-96), respectively, while for two consecutive positive tests, they were 50\% (95\% CI, 34-65) and 99\% (95\% CI, 99-99.5), respectively [31].

In addition, in our personal experience with BDG screening in 167 neutropenic patients with $\mathrm{HM}$, of whom 20 (12\%) developed invasive aspergillosis, the sensitivity was suboptimal [32]. In the per-patient analysis, sensitivity and specificity for a single positive result were, respectively, $60 \%$ and $78 \%$, and $40 \%$ and $93 \%$ for two consecutive positive results. Such high specificity was similar to that of serum GM $(90 \%)$, and in per-sample analysis, the specificity of BDG was $89-100 \%$, highlighting that in the haematology setting, persisting false positive results are not as frequent as feared. Of note, BDG became positive before GM in one-third of patients, pointing to different kinetics of fungal markers and the possibility of earlier diagnosis if more than one marker is used [32].

Similarly, in a prospective study that evaluated a combination of fungal biomarkers in 135 haematology patients, with 13 cases of IFD $(10 \%)$, the sensitivity of BDG (the Glucatell assay) at the time of diagnosis was rather low, at $69 \%$ (95\% CI 42-87), but increased to $92 \%$ when evaluated within 2 weeks of the time of diagnosis. The specificity for the cut-off of $80 \mathrm{pg} / \mathrm{mL}$ was very low $(41 \%, 95 \%$ CI 32-50) but dramatically increased if two consecutive positive results were considered ( $80 \%, 95 \%$ CI $72-87)$, without any reduction in sensitivity. Interestingly, of the various antifungal markers included, BDG was the one with best performance [33].

In conclusion, in haematology patients, serum BDG can be used in screening, keeping in mind that a negative result does not exclude the presence of IFD, and repeated testing might be required, while two consecutive positive results are associated with very high probability of true positivity and should warrant complete diagnostic workup and therapeutic decisions.

A practical approach to the use of a positive BDG result in patients with HM is shown in Figure 1.

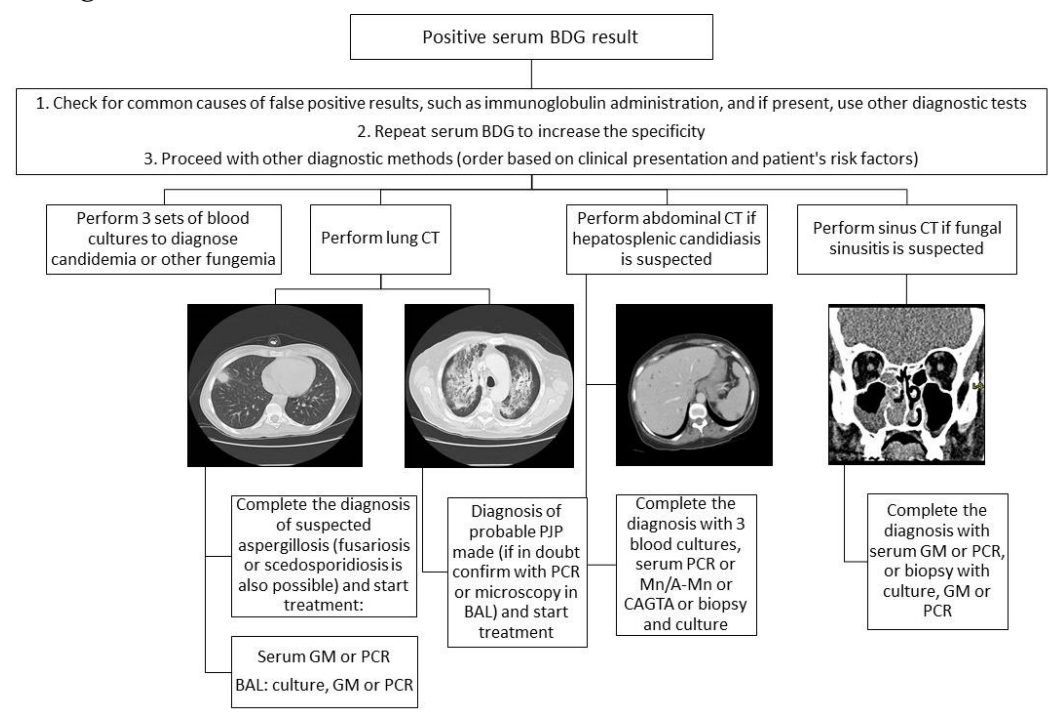

Figure 1. Practical approach to the use of a positive BDG result in patients with HM (BAL, bronchoalveolar lavage; CAGTA, Candida albicans germ-tube antibody IgG assay; CT, computed tomography; Mn/A-Mn, mannan antigen and anti-mannan antibodies; PCR, polymerase chain reaction). 


\section{BDG in Diagnosis of Invasive Candidiasis and Invasive Aspergillosis}

There are no data in haematology patients specifically on the performance of BDG in candidiasis, possibly because this IFD is not very frequent in patients routinely undergoing screening with fungal markers due to Candida-active prophylaxis. Indeed, the incidence rates of candidemia and chronic disseminated candidiasis in 3027 patients with HM ranged between $0.74-0.77$ and $0.30-0.44$ according to the group of patients [34]. However, comparison of the performance of BDG in different IFDs has been reported in recent studies.

In the study by Alanio and colleagues, which focused on the comparison of two different BDG assays, the sensitivity of both assays for the diagnosis of IA was significantly lower than for candidiasis or PJP: 57\% (95\% CI 18-90) for IA vs. 72\% (95\% 39-94) for IC vs. $79 \%$ (95\% 49-95) for PJP for the Fungitell assay [12].

Similar results were observed in a study that included 143 patients with proven or probable IFDs ( 49 cases of IC, 45 IA, and 49 rare IFDs) and analysed BDG with the Fungitell assay. At the time of diagnosis, the sensitivity of BDG was $64 \%$ in patients with candidemia, $52 \%$ in those with probable/proven IA, and $61 \%$ in those with rare IFDs [35]. There was no correlation between negative BDG results and patients' characteristics, localization of infection, or prior antifungal use, but the sensitivity was higher in the case of $C$. albicans infections compared to other Candida species.

In a recent prospective Australian experience of BDG screening of 57 episodes in 52 haematology patients at high risk of IFD, eight episodes of proven/probable IFD and 18 episodes of possible IFD were diagnosed [36]. Most of the patients received antifungals, either in prophylaxis or treatment. Overall, BDG resulted positive in $32 \%$ of samples, but the sensitivity of BDG for proven/probable IFD was only $5 / 8$ for a single positive sample and $3 / 8$ for two consecutive positive samples, while BDG was positive in the absence of IFD (false positive) in $8 / 11$ episodes. The reasons for such a poor performance remain unknown, with cyclosporine and methotrexate therapy found associated with false positive results, possibly due to circulating endogenous glucans from increased gut permeability [36]. Low sensitivity could be influenced by the high percentage of patients (63.2\%) receiving antimould-active antifungal agents, including all patients who developed proven/probable IFDs. However, this was not assessed, as a comparator group was lacking.

\section{BDG in Diagnosis of Pneumocystosis}

The incidence of PJP has been increasing in immunocompromised patients such as haematopoietic stem cell or solid organ transplant recipients, patients with autoimmune or rheumatic immune diseases, and patients undergoing systemic chemotherapy [37,38]. Mortality rates are significantly higher in immunocompromised non-human immunodeficiency virus (HIV) patients [39], possibly due to delayed diagnosis, more severe disease at presentation, greater medical complexity of the patient, and competing risk of death from underlying illnesses [40].

Among the factors contributing to increased PCP-related mortality in non-HIV-infected individuals is timely diagnosis; this is crucial for the improvement of PCP-related prognosis. Based on the Revised EORTC/MSGERC Invasive Fungal Disease Definitions for Pneumocystis jirovecii Disease in Individuals Without Human Immunodeficiency Virus, the diagnosis of proven PCP is based on clinical and radiologic criteria plus demonstration of $P$. jirovecii by microscopy using conventional or immunofluorescence staining in tissue or respiratory tract specimens [1]. Probable PJP is defined by the presence of appropriate host factors and clinical-radiologic criteria, plus amplification of $P$. jirovecii DNA by quantitative real-time PCR in respiratory specimens and/or detection of $\beta$-d-glucan in serum, provided that another invasive fungal disease and a false-positive result can be ruled out. The inclusion of the serum BDG test is based on high sensitivity and excellent negative-predictive value; uniformly accepted thresholds, however, have not been defined [41].

BDG is a non-invasive test to support the diagnosis of PJP, especially in situations where critical illness precludes invasive diagnostic procedures [42]. Given its high sensitivity, a negative BDG result has been proposed as an important test that could contribute 
to rule out a diagnosis of PJP; in ECIL guidelines for patients with HM, negative serum BDG was considered (with the grading of A II) sufficient to rule out PJP [43]. This recommendation was based on a very high negative predictive value in two meta-analyses, which was $>94 \%$ even in the case of a prevalence of PJP of 50\% [43]. However, studies that have demonstrated that a high level of BDG is a discriminative marker of PCP in immunocompromised patients were mainly focused on HIV-infected patients [44-46] or on mixed populations of HIV and non-HIV infected patients [46-52]. There are fewer studies only involving non-HIV patients.

In fact, some recent studies have highlighted lower than previously reported sensitivity of BDG in non-HIV patients with PJP. The study by Damiani and colleagues evaluated the performance of BDG assay in 39 patients with systemic autoimmune or inflammatory disorders, solid organ transplant, hematologic malignancy, or cancer with proven PJP, as well as 39 Pneumocystis-colonized patients (defined as positive PCR assay, negative microscopy, and clinical improvement in the absence of pneumocystis-active treatment) matched by an underlying condition. In this study, the BDG test had a sensitivity of $87 \%$, specificity of $97 \%$, positive predictive value of $97 \%$, and negative predictive value of $88 \%$. The median BDG level was lower in the group of PJP patients with hematologic malignancy $(211 \mathrm{pg} / \mathrm{mL}$ ) compared to the levels observed in solid organ transplant patients $(3473 \mathrm{pg} / \mathrm{mL})$ or in patients with autoimmune or inflammatory disorders $(3480 \mathrm{pg} / \mathrm{mL})$ with proven PJP. Indeed, the authors concluded that in patients with HM, with a BDG sensitivity of $64 \%$ and negative predictive value of $73 \%$, a negative BDG result alone is not sufficient to rule out PJP [53]. Similarly, in 18 patients with HM and proven/probable PJP, median BDG levels were high in those with proven $(1108 \mathrm{pg} / \mathrm{mL})$ and probable (612 pg/mL) infection, making BDG potentially helpful, but the sensitivity (83-89\%) was considered insufficient to exclude PJP [47]. Additionally, in a retrospective study of $31 \mathrm{HIV}$ positive and 44 non-HIV patients with PJP, BDG positivity was $72.7 \%$ in non-HIV vs. $93.5 \%$ in HIV groups $(p=0.034)$ [54].

Finally, a systematic review and meta-analysis of the utility of serum BDG testing, studying 997 patients with PCP and 3062 controls, reported significantly lower sensitivity in non-HIV patients compared to the HIV population (94\% vs. $86 \%)$, with a similar specificity of $79 \%(95 \%$ CI, 72-84\%) [52]. In fact, the authors concluded that a negative BDG test is only associated with a low post-test probability of PCP $(\leq 5 \%)$ when the pre-test probability is low $(\leq 20 \%)$ in patients without HIV [52]. These differences might be due to the fact that the burden of $P$. jirovecii organisms in the lungs of HIV patients with PJP is higher than that in non-HIV PCP patients [55].

The results of recent studies on the performance of BDG in PJP, with particular attention to the cut-off used and the comparator group, are presented in Table $3[42,47,53,56]$.

Another interesting issue is the potential of serum BDG to distinguish between infection and colonisation in Pneumocystis-PCR positive patients. A retrospective study performed in a mixed population of $166 \mathrm{HIV}$ and non-HIV patients (patients with HM, collagen vascular disease, solid tumour, and organ transplantation) found that BDG levels (measured with the Wako assay) in the definite PJP group were significantly higher than those in the groups of negative, colonization, and probable PJP (all $p<0.001$ ) [57]. Serum BDG levels in patients with definite/probable PJP were also significantly higher than those in patients with colonization who had positive PCR results but improved without antipneumocystis treatment. The cut-off level for discrimination was estimated at $33.5 \mathrm{pg} / \mathrm{mL}$, and the authors suggested that a positive BDG result might be a good indicator for beginning anti-PJP treatment [57]. Additionally, in solid cancer and hematologic malignancy patients with unexplained lung infiltrates, higher BDG values ( $>200 \mathrm{pg} / \mathrm{mL}$ with Fungitell assay) were consistently associated with clinical PJP among BAL PCR-positive patients, while patients with negative BDG and PCR were unlikely to have PJP (for details on different cut-offs, see Table 3) [42]. 
Table 3. The performance of BDG assays in recent studies on pneumocystosis in patients with haematological malignancies (HM).

\begin{tabular}{|c|c|c|c|c|c|c|c|}
\hline Study & Patients & Comparison & $\begin{array}{l}\text { Cut-Off, } \\
\mathrm{pg} / \mathrm{mL}\end{array}$ & $\begin{array}{c}\text { Sensitivity \% } \\
(95 \% \text { CI })\end{array}$ & $\begin{array}{l}\text { Specificity \% } \\
\text { (95\% CI) }\end{array}$ & PPV (95\% CI) & NPV (95\% CI) \\
\hline \multirow{10}{*}{$\begin{array}{l}\text { Engsbro et al., } \\
2019 \text { [47] }\end{array}$} & \multirow{10}{*}{$\begin{array}{c}\mathrm{N}=45, \mathrm{HIV}, \mathrm{SOT}, \\
\mathrm{HSCT}, \mathrm{HM}, \text { solid } \\
\text { cancer }\end{array}$} & \multicolumn{6}{|c|}{ BDG compared to immunofluorescence microscopy } \\
\hline & & \multirow[b]{2}{*}{ All patients } & 60 & $89(52-100)$ & \multirow{2}{*}{$\begin{array}{l}48(23-72) \\
65(38-86)\end{array}$} & & \\
\hline & & & 80 & $89(52-100)$ & & & \\
\hline & & \multirow{2}{*}{$\begin{array}{l}\text { PCR-positive } \\
\text { patients }\end{array}$} & 60 & $100(16-100)$ & \multirow{2}{*}{$\begin{array}{l}71(29-96) \\
74(54-89) \\
\end{array}$} & & \\
\hline & & & 80 & $100(16-100)$ & & & \\
\hline & & \multicolumn{6}{|c|}{ BDG compared to clinical categorization } \\
\hline & & \multirow{2}{*}{ All patients } & 60 & 89 (65-99) & \multirow{2}{*}{$\begin{array}{l}64(42-81) \\
74(54-89)\end{array}$} & & \\
\hline & & & 80 & $83(59-96)$ & & & \\
\hline & & \multirow{2}{*}{$\begin{array}{l}\text { PCR-positive } \\
\text { patients }\end{array}$} & 60 & 87 (59-98) & \multirow{2}{*}{$\begin{array}{l}100(16-100) \\
100(16-100)\end{array}$} & & \\
\hline & & & 80 & $80(52-96)$ & & & \\
\hline \multirow{3}{*}{$\begin{array}{l}\text { Morjaria et al., } \\
2019 \text { [42] }\end{array}$} & \multirow{3}{*}{$\begin{array}{c}\mathrm{N}=53 \mathrm{HM}, \mathrm{HSCT} \\
\text { solid cancer }\end{array}$} & \multicolumn{6}{|c|}{ BDG performance vs. PCR in PCR-positive cases } \\
\hline & & $\begin{array}{l}\text { Definite/Probable } \\
\text { PJP }\end{array}$ & 80 & $87 \%$ & $84.6 \%$ & 94.6 & 68.8 \\
\hline & & $\begin{array}{l}\text { Definite/Probable } \\
\text { PJP }\end{array}$ & 200 & $70 \%$ & $100 \%$ & 100 & 52 \\
\hline \multirow{4}{*}{$\begin{array}{l}\text { Szvalb et al., } \\
2020 \text { [56] }\end{array}$} & \multirow{4}{*}{$\begin{array}{l}\mathrm{N}=101 \mathrm{HM} \\
\text { Solid cancer }\end{array}$} & \multicolumn{6}{|c|}{ BDG performance in PCR-positive cases } \\
\hline & & & 80 & $53.5(43.8-62.9)$ & $78.4(67.7-86.2)$ & $7.8(4.4-11.2)$ & $98.0(97.6-98.5)$ \\
\hline & & & 200 & $41.6(32.5-51.3)$ & 87.8 (78.5-93.5) & $10.4(4.3-16.5)$ & $97.8(97.4-98.2)$ \\
\hline & & & 400 & $35.6(27.0-45.4)$ & $93.2(85.1-97.1)$ & $15.2(3.8-26.5)$ & 97.7 (97.3-98.1) \\
\hline \multirow{3}{*}{$\begin{array}{c}\text { Damiani et al., } \\
2021 \text { [53] }\end{array}$} & \multirow{3}{*}{$\begin{array}{c}\mathrm{N}=39 \text { Systemic } \\
\text { autoimmune or } \\
\text { inflammatory } \\
\text { disorder, SOT, HM, } \\
\text { solid cancer }\end{array}$} & \multicolumn{6}{|c|}{ Proven PJP, defined as a positive microscopic detection of $P$. jirovecii in BAL } \\
\hline & & \multirow{2}{*}{$\begin{array}{l}\text { All patients } \\
\text { Only HM } \\
\text { population }\end{array}$} & 80 & $87(73-94)$ & 97 (87-99) & $97(85-99)$ & $88(75-95)$ \\
\hline & & & 80 & $64(35-85)$ & $100(74-100)$ & $100(64-100)$ & $73(48-89)$ \\
\hline
\end{tabular}

BDG, serum (1,3)-beta-D glucan; CI, Confidence Interval; HIV, Human Immunodeficiency Virus; SOT, Solid Organ Transplant; HSCT, Hematopoietic Stem Cell Transplantation, HM, Hematologic Malignancy.

As far the correlation between BAL quantitative Pneumocystis-DNA PCR and serum BDG in various patient populations is concerned, a good correlation can be obtained in HIV patients and solid organ transplant recipients, but no correlation was observed in patients with hematologic malignancies, solid cancer, and systemic diseases. This observation added to recent data suggesting that BDG is not the perfect marker of PJP in non-HIV patients, with potential false positives due to other IFDs or bacterial infections and false negatives due to low fungal load and low BDG release [58].

It is still undefined whether serum BDG can reflect the severity or prognosis of PJP infection and predict treatment response or outcome [59].

In conclusion, parallel to the increasing incidence of non-HIV immunocompromised patients with PJP, the data from this population on BDG have increased, highlighting that there may be important differences in BDG test performance between different subsets of patients. In general, BDG detection for PJP diagnosis has adequate sensitivity and can provide helpful diagnostic support, especially when invasive testing for PCP is not feasible. A positive BDG result should trigger tests to also exclude other IFDs in these vulnerable immunocompromised patients, while a negative result in a patient with $\mathrm{HM}$ with compatible clinical presentation warrants the confirmation of the absence of PJP with negative BAL PCR or microscopy.

Additionally, in the evaluation of the performance of BDG, the "comparator test" differed across the various studies, so the new definition provided by EORTC/MSGERC might be helpful to uniformly define proven and probable populations [1]. Last but not least, different cut-offs of various commercial assays used to define positivity might further affect studies' comparability. 


\section{BDG in Other Invasive Fungal Diseases}

BDG has been reported to be positive in numerous other fungal infections, including the more common fusariosis or scedosporidiosis and the rare Exserohilum rostratum, a fungus associated with the widespread outbreak of iatrogenic CNS infections [60].

Two recent papers have highlighted its use in fusariosis. In a retrospective study of 13 patients, BDG was positive in 12 patients (92\%), in a median of 10 days (range 1-32) before the time of diagnosis [61]. Unfortunately, there was also a very high rate of positivity in the 13 selected cohorts, yielding a PPV of $7 \%$. In addition, in a cohort of eight cases of fusariosis in Spain, beta-D-glucan was positive in 100\% of cases, while GM only in 37.5\% [62].

Interestingly, in an outbreak of six cases of Saprochaete clavata infections (a fungus formerly called Geotrichum clavatum and known for its resistance to echinocandins), BDG was positive in three patients, with the serum positivity levels ranging from 159 to $>523 \mathrm{pg} / \mathrm{mL}$ [63].

\section{BDG in Samples Other Than Serum}

Currently, BDG is only approved for the use in serum; however, testing in other samples, sterile and not sterile, has been studied and successfully used in clinical practice.

Among them, the performance in cerebrospinal fluid (CSF) is particularly interesting. Although not limited to haematology patients, a systematic review of BDG in CSF included 14 studies and various fungi such as Candida, Aspergillus, Exserohilum, and Histoplasma [64]. Fox example, for Histoplasma meningitis, BDG was found to have $53 \%$ sensitivity and $87 \%$ specificity, while for Exserohilum rostratum it was 100\% and $98 \%$, respectively, for the cut-off of $138 \mathrm{pg} / \mathrm{mL}$. Although most cryptococci are thought to not contain BDG, in an HIV-positive cohort with cryptococcal meningitis, CSF BDG sensitivity was $89 \%$ and specificity $85 \%$ [65].

On the contrary, the detection of BDG in BAL has been repeatedly found to have very poor specificity and is therefore of little use [66,67]. Its potential to be used to rule out aspergillosis, which has been proposed for the ICU setting, should be confirmed in other studies [66].

\section{BDG in Children with Haematological Malignancies Undergoing Antineoplastic Chemotherapy or Stem Cell Transplantation}

Recent review papers [68-70] showed a poor performance of the test in paediatrics, unless using a cut-off much higher than the $80 \mathrm{pg} / \mathrm{mL}$, indicated as a threshold for a positive test [68]; it is discouraged for prospective monitoring or diagnostic use in paediatric patients at high risk of invasive fungal disease in the most recent guideline on management of IFD in children receiving chemotherapy or SCT (grade D recommendation, level of evidence II) [71]. Recently, BDG has been proposed in combination with GM and Aspergillus PCR for the diagnosis of invasive aspergillosis in paediatric patients [72]. The performance of the test was improved using a higher cut-off $(>300 \mathrm{pg} / \mathrm{mL})$ and using the test only after the acute post-transplant phase, where a high proportion of false positive results were observed [72].

\section{BDG for Monitoring of Response in Invasive Fungal Diseases}

There are limited data on the kinetics of BDG decline in the case of IFDs. Although a negative slope in BDG levels correlated with successful outcome in patients with invasive candidiasis, the rate of decline might vary significantly, and values above the positivity threshold may persist after clinical cure and be of little prognostic value within a clinically meaningful timeframe $[73,74]$.

However, some positive experiences have been recently published. In the already mentioned study of 143 patients with different IFDs, in $70 \%$ of the patients with a follow-up, BDG became negative at more than 1 month for candidemia and more than 3 months for IA, and slower BG decrease in patients with candidemia was associated with deep-seated localizations [35]. The potential usefulness in deep-seated infections was also illustrated by a recent case of Aspergillus ventriculitis, in which BDG was successfully used to monitor the response and to guide the length of antifungal therapy, which was discontinued after 
two consecutive negative CSF BDG measurements a 4-week period [75]. In that case, CSF was positive for BDG at almost 2 years, with levels declining to $<200 \mathrm{pg} / \mathrm{mL}$ after the first 10 months of treatment. Similarly, in the case of Exserohilum rostratum meningitis, the persistently high levels of BDG in CSF fluid were associated with poor clinical outcome [60].

In a population of haematology patients with candidemia $(n=28)$ and chronic disseminated candidiasis $(n=12)$, BDG sensitivity was, respectively, $43.5 \%$ and $73 \%$, but its kinetics correlated with the clinical outcome, with a sharp decline in BDG levels in those with resolution of candidemia and a decrease in BDG levels within 2 to 6 months in patients with chronic candidiasis who survived. Of note, BDG negativisation preceded resolution of lesions on CT [34]. In contrast, in another recent case of proven hepatic candidiasis, the positivity of BDG lasted less than 20 days, with an important decrease 10 days after the onset of antifungal therapy [76]. In the already mentioned study in patients with fusariosis, BDG increased in patients who died by day 30 , but remained stable during this timeframe in those who survived [61].

On the other hand, there were also reported cases of prolonged BDG positivity months after the clearance of candidemia in HSCT recipients without any other IFD and in whom the central venous catheter had been removed $[77,78]$.

\section{Serum BDG in the Diagnostic Criteria of Invasive Fungal Diseases}

The contribution of the BDG test in the diagnosis of IFD in haematology patients has also been highlighted in the guidelines of the Third European Conference on Infections in Leukemia (ECIL-3), in which the use of BDG was given a B-II grading of recommendation for the diagnosis of IFD (moderate evidence for use) [31].

ESCMID guidelines recommend, with grade C II, the use of serum BDG to diagnose IFD and to diagnose and screen for IA in adults with HM and after stem cell transplant [79].

BDG was included in the first revision in 2008 of EORTC/MSG criteria for the diagnosis of IFD in the immunocompromised as a mycological criterion for the diagnosis of any probable invasive fungal disease other than cryptococcosis and mucormycosis [80]. In the second revision of the EORTC/MSG diagnostic criteria in 2019, serum BDG (two consecutive samples above $80 \mathrm{pg} / \mathrm{mL}$ for Fungitell assay) is considered as a mycological criterion only of probable invasive candidiasis or probable pneumocystosis, but not among the criteria for the diagnosis of invasive aspergillosis or other invasive mould infections [1]. This is the first time that these criteria include also pneumocystis, and in case of this IFD, both positive serum BDG and molecular detection of Pneumocystis-DNA in BAL are considered as criteria of probable infection, while microscopic detection is required for the diagnosis of proven PJP, and the basis for such classification was reviewed separately [41].

\section{Summary of Strengths and Limitations of BDG Assay}

The correct use of BDG in clinical practice requires the knowledge of its strengths and limitations, which are summarized in Table 4.

Table 4. Strengths and limitations of BDG testing in patients with haematological malignancies (HM).

\begin{tabular}{cc}
\hline Strengths & Limitations \\
\hline Almost panfungal assay [4,5] & $\begin{array}{c}\text { Not applicable to Mucorales, Blastomyces, and } \\
\text { most cryptococci [4,5] }\end{array}$ \\
\hline Rapid turnaround time (approx. 1 h) [7-11] & Batch testing required with most assays [7-11] \\
\hline $\begin{array}{c}\text { Several assays available, including a single } \\
\text { sample format [7-11] }\end{array}$ & $\begin{array}{c}\text { Not specific for any fungus and thus needs to } \\
\text { be used in combination with other diagnostic } \\
\text { methods for identification of species (GM, PCR, } \\
\text { radiology, etc.) [1] }\end{array}$ \\
\hline Used both for screening and targeted testing [1] & $\begin{array}{c}\text { Cut-off provided by manufacturers might need } \\
\text { optimizing for better performance [12,13] }\end{array}$ \\
\hline
\end{tabular}


Table 4. Cont.

\begin{tabular}{cc}
\hline Strengths & Limitations \\
\hline $\begin{array}{c}\text { In haematological patients, high specificity of } \\
\text { two consecutive positive tests [31-33] }\end{array}$ & $\begin{array}{c}\text { The need to use glucan-free laboratory } \\
\text { materials [15] }\end{array}$ \\
\hline $\begin{array}{c}\text { More sensitive than blood cultures for } \\
\text { deep-seated candidiasis [1] }\end{array}$ & $\begin{array}{c}\text { Possibility of false positive results } \\
\text { (see Table 2) [2,15-27] }\end{array}$ \\
\hline High sensitivity for PJP [53-55] & $\begin{array}{c}\text { Lower sensitivity in patients with } \\
\text { haematologic malignancies and IFD compared } \\
\text { to other patient groups [16,18] }\end{array}$ \\
\hline $\begin{array}{c}\text { The only non-invasive test to support the } \\
\text { critical illness precludes invasive diagnostic } \\
\text { procedures such as BAL [42] }\end{array}$ & $\begin{array}{c}\text { Of limited use in paediatric population [68-70] } \\
\text { Possibility of use in other sterile fluids such as } \\
\text { cerebrospinal fluid for fungal central nervous } \\
\text { system infections [64,65] }\end{array}$ \\
$\begin{array}{c}\text { In case of invasive candidiasis, lower } \\
\text { sensitivity in case of certain species, such as C. } \\
\text { parapsilosis or C. auris [19,26] }\end{array}$ \\
\hline
\end{tabular}

\section{Conclusions}

BDG is a versatile test, which can be successfully used in screening and diagnostic testing in patients with $\mathrm{HM}$ in combination with clinical assessment and other diagnostic tests, both radiological and mycological. There may be variability in PPV and NPV, based on patient population and type of IFD, and lower sensitivity if case of IA, compared to IC and PJP might be expected. In the haematology setting, NPV is insufficient to exclude diagnosis of IFD. The specificity of the test can be improved by using two consecutive positive assays and avoiding testing in the case of the concomitant presence of factors associated with false positive results, such as immunoglobulin administration. In addition, serum good performance of BDG in CSF was reported. The real-life performance of various new marketed assays will need to be determined.

Author Contributions: Conceptualization and design: M.M.; collection and assembly of data: M.M., E.B., E.C. and A.M.; manuscript writing: M.M., E.B., E.C. and A.M. All authors have read and agreed to the published version of the manuscript.

Funding: This research received no external funding.

Institutional Review Board Statement: Not applicable.

Informed Consent Statement: Not applicable.

Conflicts of Interest: MM received speaker fees from Janssen, Gilead, MSD, and Pfizer; none related to this work. EC received speaker fees from Gilead, Pfizer, Mundibiopharma, and Astellas; none related to this work. All other authors: noting to declare.

\section{References}

1. Donnelly, J.P.; Chen, S.C.; Kauffman, C.A.; Steinbach, W.J.; Baddley, J.W.; Verweij, P.E.; Clancy, C.J.; Wingard, J.R.; Lockhart, S.R.; Groll, A.H.; et al. Revision and Update of the Consensus Definitions of Invasive Fungal Disease from the European Organization for Research and Treatment of Cancer and the Mycoses Study Group Education and Research Consortium. Clin. Infect. Dis. 2020, 71, 1367-1376. [CrossRef]

2. Giacobbe, D.R.; Del Bono, V.; Viscoli, C.; Mikulska, M. Use of 1,3- $\beta$-D-glucan in invasive fungal diseases in hematology patients. Expert Rev. Anti-Infect. Ther. 2017, 15, 1101-1112. [CrossRef] [PubMed] 
3. Lanternier, F.; Seidel, D.; Pagano, L.; Styczynski, J.; Mikulska, M.; Pulcini, C.; Maertens, J.; Munoz, P.; Garcia-Vidal, C.; Rijnders, B.; et al. Invasive pulmonary aspergillosis treatment duration in haematology patients in Europe: An EFISG, IDWPEBMT, EORTC-IDG and SEIFEM survey. Mycoses 2020, 63, 420-429. [CrossRef] [PubMed]

4. Odabasi, Z.; Paetznick, V.L.; Rodriguez, J.R.; Chen, E.; McGinnis, M.R.; Ostrosky-Zeichner, L. Differences in beta-glucan levels in culture supernatants of a variety of fungi. Med. Mycol. 2006, 44, 267-272. [CrossRef]

5. Obayashi, T.; Yoshida, M.; Mori, T.; Goto, H.; Yasuoka, A.; Iwasaki, H.; Teshima, H.; Kohno, S.; Horiuchi, A.; Ito, A.; et al. Plasma (1->3)-beta-D-glucan measurement in diagnosis of invasive deep mycosis and fungal febrile episodes. Lancet 1995, 345, 17-20. [CrossRef]

6. White, S.K.; Schmidt, R.L.; Walker, B.S.; Hanson, K.E. (1 $\rightarrow 3)$ - $\beta$-D-glucan testing for the detection of invasive fungal infections in immunocompromised or critically ill people. Cochrane Database Syst. Rev. 2020, 7, Cd009833. [CrossRef] [PubMed]

7. Lass-Flörl, C.; Samardzic, E.; Knoll, M. Serology anno 2021-fungal infections: From invasive to chronic. Clin. Microbiol. Infect. 2021, 27, 1230-1241. [CrossRef]

8. Lamoth, F.; Akan, H.; Andes, D.; Cruciani, M.; Marchetti, O.; Ostrosky-Zeichner, L.; Racil, Z.; Clancy, C.J. Assessment of the Role of 1,3- $\beta$-d-Glucan Testing for the Diagnosis of Invasive Fungal Infections in Adults. Clin. Infect. Dis. 2021, 72, S102-S108. [CrossRef]

9. White, S.K.; Walker, B.S.; Hanson, K.E.; Schmidt, R.L. Diagnostic Accuracy of $\beta$-d-Glucan (Fungitell) Testing Among Patients with Hematologic Malignancies or Solid Organ Tumors: A Systematic Review and Meta-Analysis. Am. J. Clin. Pathol. 2019, 151, 275-285. [CrossRef]

10. Bamba, Y.; Nagano, K.; Moro, H.; Ogata, H.; Hakamata, M.; Shibata, S.; Koizumi, T.; Aoki, N.; Ohshima, Y.; Watanabe, S.; et al. Efficacy of the new $\beta$-D-glucan measurement kit for diagnosing invasive fungal infections, as compared with that of four conventional kits. PLoS ONE 2021, 16, e0255172. [CrossRef]

11. D'Ordine, R.L.; Garcia, K.A.; Roy, J.; Zhang, Y.; Markley, B.; Finkelman, M.A. Performance characteristics of Fungitell STAT ${ }^{\mathrm{TM}}$, a rapid $(1 \rightarrow 3)-\beta$-D-glucan single patient sample in vitro diagnostic assay. Med. Mycol. 2021, 59, 41-49. [CrossRef]

12. Alanio, A.; Gits-Muselli, M.; Guigue, N.; Denis, B.; Bergeron, A.; Touratier, S.; Hamane, S.; Bretagne, S. Prospective comparison of (1,3)-beta-D-glucan detection using colorimetric and turbidimetric assays for diagnosing invasive fungal disease. Med. Mycol. 2021, 59, 882-889. [CrossRef]

13. Mercier, T.; Guldentops, E.; Patteet, S.; Beuselinck, K.; Lagrou, K.; Maertens, J. Beta-d-Glucan for Diagnosing Pneumocystis Pneumonia: A Direct Comparison between the Wako $\beta$-Glucan Assay and the Fungitell Assay. J. Clin. Microbiol. 2019, 57, e00322-19. [CrossRef]

14. He, S.; Hang, J.P.; Zhang, L.; Wang, F.; Zhang, D.C.; Gong, F.H. A systematic review and meta-analysis of diagnostic accuracy of serum 1,3-beta-D-glucan for invasive fungal infection: Focus on cutoff levels. J. Microbiol. Immunol. Infect. 2015, 48, 351-361. [CrossRef] [PubMed]

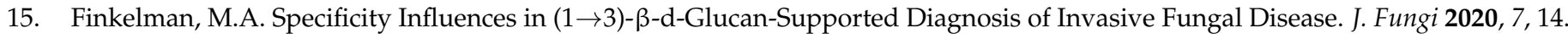
[CrossRef]

16. Abe, M.; Kimura, M.; Araoka, H.; Taniguchi, S.; Yoneyama, A. Serum (1,3)-beta-D-glucan is an inefficient marker of breakthrough candidemia. Med. Mycol. 2014, 52, 835-840. [CrossRef]

17. Bougnoux, M.E.; Angebault, C.; Paccoud, O.; Coignard, H.; Lanternier, F.; Lortholary, O. Impact of intravenous and subcutaneous immunoglobulins on false positivity of galactomannan and beta-D-glucan antigenaemia and detection of circulating Aspergillus fumigatus DNA. Clin. Microbiol. Infect. 2020, 26, 1101-1102. [CrossRef] [PubMed]

18. Chang, E.; Kim, T.S.; Kang, C.K.; Jun, K.I.; Shin, D.; Koh, Y.; Hong, J.; Choe, P.G.; Park, W.B.; Kim, N.J.; et al. Limited Positive Predictive Value of beta-d-Glucan in Hematologic Patients Receiving Antimold Prophylaxis. Open Forum Infect. Dis. 2020, 7, ofaa048. [CrossRef] [PubMed]

19. Farooqi, J.; Niamatullah, H.; Irfan, S.; Zafar, A.; Malik, F.; Jabeen, K. Comparison of beta-D-Glucan levels between Candida auris and other Candida species at the time of candidaemia: A retrospective study. Clin. Microbiol. Infect. 2021, 27, 1519.e1-1519.e5. [CrossRef]

20. Finkelman, M.A. Comment on: 1,3-beta-d-Glucan contamination of common antimicrobials. J. Antimicrob. Chemother. 2016, 71, 2996-2997. [CrossRef] [PubMed]

21. Furfaro, E.; Mikulska, M.; Del Bono, V.; Guolo, F.; Minetto, P.; Gobbi, M.; Ghiso, A.; Bacigalupo, A.; Viscoli, C. Bloodstream infections are an improbable cause of positive serum (1,3)-beta-D-glucan in hematology patients. Clin. Vaccine Immunol. 2014, 21, 1357-1359. [CrossRef] [PubMed]

22. Pickering, J.W.; Sant, H.W.; Bowles, C.A.; Roberts, W.L.; Woods, G.L. Evaluation of a (1->3)-beta-D-glucan assay for diagnosis of invasive fungal infections. J. Clin. Microbiol. 2005, 43, 5957-5962. [CrossRef]

23. Holstein, M.; Jang, D.; Urrea, C.; Botta, L.S.; Grimm, W.; Ghose, S.; Li, Z.J. Control of leached beta-glucan levels from depth filters by an improved depth filtration flush strategy. Biotechnol. Prog. 2021, 37, e3086. [CrossRef] [PubMed]

24. Kaita, Y.; Tarui, T.; Otsu, A.; Tanaka, Y.; Suzuki, J.; Yoshikawa, K.; Yamaguchi, Y. The Clinical Significance of Serum 1,3-beta-DGlucan for the Diagnosis of Candidemia in Severe Burn Patients. J. Burn Care Res. 2019, 40, 104-106. [CrossRef] [PubMed]

25. Kanamori, H.; Kanemitsu, K.; Miyasaka, T.; Ameku, K.; Endo, S.; Aoyagi, T.; Inden, K.; Hatta, M.; Yamamoto, N.; Kunishima, H.; et al. Measurement of (1-3)-beta-D-glucan derived from different gauze types. Tohoku J. Exp. Med. 2009, 217, 117-121. [CrossRef] 
26. Mikulska, M.; Giacobbe, D.R.; Furfaro, E.; Mesini, A.; Marchese, A.; Del Bono, V.; Viscoli, C. Lower sensitivity of serum (1,3)-beta-d-glucan for the diagnosis of candidaemia due to Candida parapsilosis. Clin. Microbiol. Infect. 2016, 22, 646.e5-646.e8. [CrossRef]

27. Prattes, J.; Schneditz, D.; Pruller, F.; Jaindl, E.; Sauseng, N.; Hoenigl, M.; Schilcher, G.; Krause, R. 1,3-ss-d-Glucan testing is highly specific in patients undergoing dialysis treatment. J. Infect. 2017, 74, 72-80. [CrossRef]

28. Hashimoto, N.; Mori, T.; Hashida, R.; Sakurai, M.; Koda, Y.; Toyama, T.; Kato, J.; Okamoto, S. False-positive serum (1, 3)- $\beta$-Dglucan elevation due to intake of seaweed in a hematopoietic stem cell transplant recipient. Transpl. Infect. Dis. 2017, 19, e12653. [CrossRef]

29. Ito, S.; Ashizawa, M.; Sasaki, R.; Ikeda, T.; Toda, Y.; Mashima, K.; Umino, K.; Minakata, D.; Nakano, H.; Yamasaki, R.; et al. False-positive elevation of 1,3-beta-D-glucan caused by continuous administration of penicillin G. J. Infect. Chemother. 2018, 24, 812-814. [CrossRef]

30. Zhang, L.; Guo, Z.; Xie, S.; Zhou, J.; Chen, G.; Feng, J.; Huang, Y. The performance of galactomannan in combination with 1,3- $\beta$-D-glucan or aspergillus-lateral flow device for the diagnosis of invasive aspergillosis: Evidences from 13 studies. Diagn. Microbiol. Infect. Dis. 2019, 93, 44-53. [CrossRef]

31. Lamoth, F.; Cruciani, M.; Mengoli, C.; Castagnola, E.; Lortholary, O.; Richardson, M.; Marchetti, O. $\beta$-Glucan antigenemia assay for the diagnosis of invasive fungal infections in patients with hematological malignancies: A systematic review and meta-analysis of cohort studies from the Third European Conference on Infections in Leukemia (ECIL-3). Clin. Infect. Dis 2012, 54, 633-643. [CrossRef] [PubMed]

32. Furfaro, E.; Giacobbe, D.R.; Del Bono, V.; Signori, A.; Guolo, F.; Minetto, P.; Clavio, M.; Ballerini, F.; Gobbi, M.; Viscoli, C.; et al. Performance of serum $(1,3)-\beta$-d-glucan screening for the diagnosis of invasive aspergillosis in neutropenic patients with haematological malignancies. Mycoses 2018, 61, 650-655. [CrossRef] [PubMed]

33. Hammarström, H.; Stjärne Aspelund, A.; Christensson, B.; Heußel, C.P.; Isaksson, J.; Kondori, N.; Larsson, L.; Markowicz, P.; Richter, J.; Wennerås, C.; et al. Prospective evaluation of a combination of fungal biomarkers for the diagnosis of invasive fungal disease in high-risk haematology patients. Mycoses 2018, 61, 623-632. [CrossRef]

34. Guitard, J.; Isnard, F.; Tabone, M.D.; Antignac, M.; Brissot, E.; Senghor, Y.; Petit, A.; Leverger, G.; Hennequin, C. Usefulness of ß-D-glucan for diagnosis and follow-up of invasive candidiasis in onco-haematological patients. J. Infect. 2018, 76, 483-488. [CrossRef]

35. Angebault, C.; Lanternier, F.; Dalle, F.; Schrimpf, C.; Roupie, A.L.; Dupuis, A.; Agathine, A.; Scemla, A.; Paubelle, E.; Caillot, D.; et al. Prospective Evaluation of Serum $\beta$-Glucan Testing in Patients with Probable or Proven Fungal Diseases. Open Forum Infect. Dis. 2016, 3, ofw128. [CrossRef]

36. Garnham, K.; Halliday, C.L.; Joshi Rai, N.; Jayawadena, M.; Hasan, T.; Kok, J.; Nayyar, V.; Gottlieb, D.J.; Gilroy, N.M.; Chen, S.C. Introducing 1,3-Beta-D-glucan for screening and diagnosis of invasive fungal diseases in Australian high risk haematology patients: Is there a clinical benefit? Intern. Med. J. 2020. [CrossRef]

37. Schmidt, J.J.; Lueck, C.; Ziesing, S.; Stoll, M.; Haller, H.; Gottlieb, J.; Eder, M.; Welte, T.; Hoeper, M.M.; Scherag, A.; et al. Clinical course, treatment and outcome of Pneumocystis pneumonia in immunocompromised adults: A retrospective analysis over 17 years. Crit. Care 2018, 22, 307. [CrossRef]

38. Maini, R.; Henderson, K.L.; Sheridan, E.A.; Lamagni, T.; Nichols, G.; Delpech, V.; Phin, N. Increasing Pneumocystis pneumonia, England, UK, 2000-2010. Emerg. Infect. Dis. 2013, 19, 386-392. [CrossRef]

39. Bienvenu, A.L.; Traore, K.; Plekhanova, I.; Bouchrik, M.; Bossard, C.; Picot, S. Pneumocystis pneumonia suspected cases in 604 non-HIV and HIV patients. Int. J. Infect. Dis. 2016, 46, 11-17. [CrossRef] [PubMed]

40. Salzer, H.J.F.; Schäfer, G.; Hoenigl, M.; Günther, G.; Hoffmann, C.; Kalsdorf, B.; Alanio, A.; Lange, C. Clinical, Diagnostic, and Treatment Disparities between HIV-Infected and Non-HIV-Infected Immunocompromised Patients with Pneumocystis jirovecii Pneumonia. Respiration 2018, 96, 52-65. [CrossRef]

41. Lagrou, K.; Chen, S.; Masur, H.; Viscoli, C.; Decker, C.F.; Pagano, L.; Groll, A.H. Pneumocystis jirovecii Disease: Basis for the Revised EORTC/MSGERC Invasive Fungal Disease Definitions in Individuals Without Human Immunodeficiency Virus. Clin. Infect. Dis. 2021, 72, S114-S120. [CrossRef]

42. Morjaria, S.; Frame, J.; Franco-Garcia, A.; Geyer, A.; Kamboj, M.; Babady, N.E. Clinical Performance of $(1,3)$ Beta-D Glucan for the Diagnosis of Pneumocystis Pneumonia (PCP) in Cancer Patients Tested with PCP Polymerase Chain Reaction. Clin. Infect. Dis. 2019, 69, 1303-1309. [CrossRef]

43. Alanio, A.; Hauser, P.M.; Lagrou, K.; Melchers, W.J.; Helweg-Larsen, J.; Matos, O.; Cesaro, S.; Maschmeyer, G.; Einsele, H.; Donnelly, J.P.; et al. ECIL guidelines for the diagnosis of Pneumocystis jirovecii pneumonia in patients with haematological malignancies and stem cell transplant recipients. J. Antimicrob. Chemother. 2016, 71, 2386-2396. [CrossRef]

44. Salerno, D.; Mushatt, D.; Myers, L.; Zhuang, Y.; de la Rua, N.; Calderon, E.J.; Welsh, D.A. Serum and bal beta-D-glucan for the diagnosis of Pneumocystis pneumonia in HIV positive patients. Respir. Med. 2014, 108, 1688-1695. [CrossRef]

45. Hammarström, H.; Grankvist, A.; Broman, I.; Kondori, N.; Wennerås, C.; Gisslen, M.; Friman, V. Serum-based diagnosis of Pneumocystis pneumonia by detection of Pneumocystis jirovecii DNA and 1,3- $\beta$-D-glucan in HIV-infected patients: A retrospective case control study. BMC Infect. Dis. 2019, 19, 658. [CrossRef] 
46. Esteves, F.; Lee, C.H.; de Sousa, B.; Badura, R.; Seringa, M.; Fernandes, C.; Gaspar, J.F.; Antunes, F.; Matos, O. (1-3)-beta-Dglucan in association with lactate dehydrogenase as biomarkers of Pneumocystis pneumonia $(\mathrm{PcP})$ in $\mathrm{HIV}$-infected patients. Eur. J. Clin. Microbiol. Infect. Dis. 2014, 33, 1173-1180. [CrossRef] [PubMed]

47. Engsbro, A.L.; Najat, S.; Jørgensen, K.M.; Kurtzhals, J.A.L.; Arendrup, M.C. Diagnostic accuracy of the 1,3- $\beta$-D-glucan test for pneumocystis pneumonia in a tertiary university hospital in Denmark: A retrospective study. Med. Mycol. 2019, 57, 710-717. [CrossRef] [PubMed]

48. Del Bono, V.; Mularoni, A.; Furfaro, E.; Delfino, E.; Rosasco, L.; Miletich, F.; Viscoli, C. Clinical evaluation of a (1,3)-beta-D-glucan assay for presumptive diagnosis of Pneumocystis jiroveci pneumonia in immunocompromised patients. Clin. Vaccine Immunol. 2009, 16, 1524-1526. [CrossRef]

49. Matsumura, Y.; Ito, Y.; Yamamoto, M.; Matsushima, A.; Nagao, M.; Takakura, S.; Iinuma, Y.; Ichiyama, S. Pneumocystis polymerase chain reaction and blood $(1 \rightarrow 3)-\beta$-D-glucan assays to predict survival with suspected Pneumocystis jirovecii pneumonia. J. Infect. Chemother. 2014, 20, 109-114. [CrossRef]

50. Li, W.J.; Guo, Y.L.; Liu, T.J.; Wang, K.; Kong, J.L. Diagnosis of pneumocystis pneumonia using serum (1-3)- $\beta$-D-Glucan: A bivariate meta-analysis and systematic review. J. Thorac. Dis. 2015, 7, 2214-2225. [CrossRef] [PubMed]

51. Karageorgopoulos, D.E.; Qu, J.M.; Korbila, I.P.; Zhu, Y.G.; Vasileiou, V.A.; Falagas, M.E. Accuracy of $\beta$-D-glucan for the diagnosis of Pneumocystis jirovecii pneumonia: A meta-analysis. Clin. Microbiol. Infect. 2013, 19, 39-49. [CrossRef]

52. Del Corpo, O.; Butler-Laporte, G.; Sheppard, D.C.; Cheng, M.P.; McDonald, E.G.; Lee, T.C. Diagnostic accuracy of serum (1-3)- $\beta$-D-glucan for Pneumocystis jirovecii pneumonia: A systematic review and meta-analysis. Clin. Microbiol. Infect. 2020, 26, 1137-1143. [CrossRef]

53. Damiani, C.; Demey, B.; Pauc, C.; Le Govic, Y.; Totet, A. A Negative (1,3)- $\beta$-D-Glucan Result Alone Is Not Sufficient to Rule Out a Diagnosis of Pneumocystis Pneumonia in Patients with Hematological Malignancies. Front. Microbiol. 2021, $12,713265$. [CrossRef] [PubMed]

54. Kato, H.; Samukawa, S.; Takahashi, H.; Nakajima, H. Diagnosis and treatment of Pneumocystis jirovecii pneumonia in HIV-infected or non-HIV-infected patients-difficulties in diagnosis and adverse effects of trimethoprim-sulfamethoxazole. J. Infect. Chemother. 2019, 25, 920-924. [CrossRef]

55. Desmet, S.; Van Wijngaerden, E.; Maertens, J.; Verhaegen, J.; Verbeken, E.; De Munter, P.; Meersseman, W.; Van Meensel, B.; Van Eldere, J.; Lagrou, K. Serum (1-3)-beta-D-glucan as a tool for diagnosis of Pneumocystis jirovecii pneumonia in patients with human immunodeficiency virus infection or hematological malignancy. J. Clin. Microbiol. 2009, 47, 3871-3874. [CrossRef] [PubMed]

56. Szvalb, A.D.; Malek, A.E.; Jiang, Y.; Bhatti, M.M.; Wurster, S.; Kontoyiannis, D.P. Serum (1,3)-Beta-d-Glucan has suboptimal performance for the diagnosis of Pneumocystis jirovecii pneumonia in cancer patients and correlates poorly with respiratory burden as measured by quantitative PCR. J. Infect. 2020, 81, 443-451. [CrossRef] [PubMed]

57. Tasaka, S.; Kobayashi, S.; Yagi, K.; Asami, T.; Namkoong, H.; Yamasawa, W.; Ishii, M.; Hasegawa, N.; Betsuyaku, T. Serum $(1 \rightarrow 3) \beta$-D-glucan assay for discrimination between Pneumocystis jirovecii pneumonia and colonization. J. Infect. Chemother. 2014, 20, 678-681. [CrossRef] [PubMed]

58. Mercier, T.; Aissaoui, N.; Gits-Muselli, M.; Hamane, S.; Prattes, J.; Kessler, H.H.; Mareković, I.; Pleško, S.; Steinmann, J.; Scharmann, U.; et al. Variable Correlation between Bronchoalveolar Lavage Fluid Fungal Load and Serum-(1,3)- $\beta$-d-Glucan in Patients with Pneumocystosis-A Multicenter ECMM Excellence Center Study. J. Fungi 2020, 6, 327. [CrossRef]

59. Urabe, N.; Sakamoto, S.; Sano, G.; Ito, A.; Sekiguchi, R.; Homma, S. Serial change in serum biomarkers during treatment of Non-HIV Pneumocystis pneumonia. J. Infect. Chemother. 2019, 25, 936-942. [CrossRef]

60. Litvintseva, A.P.; Lindsley, M.D.; Gade, L.; Smith, R.; Chiller, T.; Lyons, J.L.; Thakur, K.T.; Zhang, S.X.; Grgurich, D.E.; Kerkering, T.M.; et al. Utility of (1-3)- $\beta$-d-Glucan Testing for Diagnostics and Monitoring Response to Treatment During the Multistate Outbreak of Fungal Meningitis and Other Infections. Clin. Infect. Dis. 2013, 58, 622-630. [CrossRef]

61. Nucci, M.; Barreiros, G.; Reis, H.; Paixão, M.; Akiti, T.; Nouér, S.A. Performance of 1,3-beta-D-glucan in the diagnosis and monitoring of invasive fusariosis. Mycoses 2019, 62, 570-575. [CrossRef]

62. Fernández-Cruz, A.; Semiglia, M.A.; Guinea, J.; Martínez-Jiménez, M.D.C.; Escribano, P.; Kwon, M.; Rodríguez-Macías, G.; Chamorro-de-Vega, E.; Rodríguez-González, C.; Navarro, R.; et al. A retrospective cohort of invasive fusariosis in the era of antimould prophylaxis. Med. Mycol. 2020, 58, 300-309. [CrossRef]

63. Lo Cascio, G.; Vincenzi, M.; Soldani, F.; De Carolis, E.; Maccacaro, L.; Sorrentino, A.; Nadali, G.; Cesaro, S.; Sommavilla, M.; Niero, V.; et al. Outbreak of Saprochaete clavata Sepsis in Hematology Patients: Combined Use of MALDI-TOF and Sequencing Strategy to Identify and Correlate the Episodes. Front. Microbiol. 2020, 11, 84. [CrossRef] [PubMed]

64. Davis, C.; Wheat, L.J.; Myint, T.; Boulware, D.R.; Bahr, N.C. Efficacy of Cerebrospinal Fluid Beta-d-Glucan Diagnostic Testing for Fungal Meningitis: A Systematic Review. J. Clin. Microbiol. 2020, 58, e02094-19. [CrossRef]

65. Rhein, J.; Bahr, N.C.; Morawski, B.M.; Schutz, C.; Zhang, Y.; Finkelman, M.; Meya, D.B.; Meintjes, G.; Boulware, D.R. Detection of High Cerebrospinal Fluid Levels of $(1 \rightarrow 3)-\beta$-d-Glucan in Cryptococcal Meningitis. Open Forum Infect. Dis. 2014, 1, ofu105. [CrossRef] 
66. Boch, T.; Reinwald, M.; Spiess, B.; Liebregts, T.; Schellongowski, P.; Meybohm, P.; Rath, P.M.; Steinmann, J.; Trinkmann, F.; Britsch, S.; et al. Detection of invasive pulmonary aspergillosis in critically ill patients by combined use of conventional culture, galactomannan, 1-3-beta-D-glucan and Aspergillus specific nested polymerase chain reaction in a prospective pilot study. J. Crit. Care 2018, 47, 198-203. [CrossRef] [PubMed]

67. Bhaskaran, A.; Kabbani, D.; Singer, L.G.; Prochnow, T.; Bhimji, A.; Rotstein, C.; Finkelman, M.A.; Keshavjee, S.; Husain, S. (1,3) $\beta$-D-Glucan in Bronchoalveolar Lavage of Lung Transplant Recipients for the Diagnosis of Invasive Pulmonary Aspergillosis. Med. Mycol. 2017, 55, 173-179. [CrossRef]

68. Saffioti, C.; Mesini, A.; Bandettini, R.; Castagnola, E. Diagnosis of invasive fungal disease in children: A narrative review. Expert Rev. Anti-Infect. Ther. 2019, 17, 895-909. [CrossRef]

69. Lehrnbecher, T.; Robinson, P.D.; Fisher, B.T.; Castagnola, E.; Groll, A.H.; Steinbach, W.J.; Zaoutis, T.E.; Negeri, Z.F.; Beyene, J.; Phillips, B.; et al. Galactomannan, $\beta$-D-Glucan, and Polymerase Chain Reaction-Based Assays for the Diagnosis of Invasive Fungal Disease in Pediatric Cancer and Hematopoietic Stem Cell Transplantation: A Systematic Review and Meta-Analysis. Clin. Infect. Dis. 2016, 63, 1340-1348. [CrossRef] [PubMed]

70. Singh, S.; Singh, M.; Verma, N.; Sharma, M.; Pradhan, P.; Chauhan, A.; Jaiswal, N.; Chakrabarti, A.; Singh, M. Comparative accuracy of 1,3 beta-D glucan and galactomannan for diagnosis of invasive fungal infections in pediatric patients: A systematic review with meta-analysis. Med. Mycol. 2021, 59, 139-148. [CrossRef] [PubMed]

71. Groll, A.H.; Pana, D.; Lanternier, F.; Mesini, A.; Amman, R.; Averbuch, D.; Castagnola, E.; Cesaro, S.; Engelhard, D.; Garcia-Vidal, C.; et al. 8th European Conference on Infections in Leukaemia: 2020 guidelines for the diagnosis, prevention, and treatment of invasive fungal diseases in paediatric patients with cancer or post-haematopoietic cell transplantation. Lancet Oncol. 2021, 22, e254-e269. [CrossRef]

72. Springer, J.; Held, J.; Mengoli, C.; Schlegel, P.G.; Gamon, F.; Traeger, J.; Kurzai, O.; Einsele, H.; Loeffler, J.; Eyrich, M. Diagnostic Performance of $(1 \rightarrow 3)-\beta$-D-Glucan Alone and in Combination with Aspergillus PCR and Galactomannan in Serum of Pediatric Patients after Allogeneic Hematopoietic Stem Cell Transplantation. J. Fungi 2021, 7, 238. [CrossRef]

73. Jaijakul, S.; Vazquez, J.A.; Swanson, R.N.; Ostrosky-Zeichner, L. (1,3)- $\beta$-D-Glucan as a Prognostic Marker of Treatment Response in Invasive Candidiasis. Clin. Infect. Dis. 2012, 55, 521-526. [CrossRef]

74. Koo, S.; Baden, L.R.; Marty, F.M. Post-diagnostic kinetics of the $(1 \rightarrow 3)-\beta$-D-glucan assay in invasive aspergillosis, invasive candidiasis and Pneumocystis jirovecii pneumonia. Clin. Microbiol Infect. 2012, 18, E122-E127. [CrossRef]

75. Chen, T.K.; Groncy, P.K.; Javahery, R.; Chai, R.Y.; Nagpala, P.; Finkelman, M.; Petraitiene, R.; Walsh, T.J. Successful treatment of Aspergillus ventriculitis through voriconazole adaptive pharmacotherapy, immunomodulation, and therapeutic monitoring of cerebrospinal fluid (1 $\rightarrow 3)-\beta$-D-glucan. Med. Mycol. 2017, 55, 109-117. [CrossRef] [PubMed]

76. Della Pepa, R.; Cerchione, C.; Pugliese, N.; Colicchio, R.; Salvatore, P.; Sirignano, C.; Soscia, E.; Pagano, L.; Sanguinetti, M.; Pane, F.; et al. Diagnostic-driven antifungal approach in neutropenic patients at high risk for chronic disseminated candidiasis: Preliminary observations on the role of $1,3-\beta-D$-glucan antigenemia and multiphasic contrast-enhanced computed tomography. Support. Care Cancer 2018, 26, 1691-1694. [CrossRef] [PubMed]

77. Mikulska, M.; Furfaro, E.; Del Bono, V.; Gualandi, F.; Van Lint, M.T.; Miletich, F.; Bacigalupo, A.; Viscoli, C. Persistence of a positive (1,3)-beta-D-glucan test after clearance of candidemia in hematopoietic stem cell transplant recipients. Clin. Vaccine Immunol. 2011, 18, 518-519. [CrossRef]

78. Naselli, A.; Faraci, M.; Lanino, E.; Morreale, G.; Cangemi, G.; Bandettini, R.; Castagnola, E. Persistence of high-level (1,3)- $\beta$-Dglucan after candidemia following autologous peripheral SCT in a pediatric patient. Bone Marrow Transplant. 2015, 50, 137-138. [CrossRef] [PubMed]

79. Ullmann, A.J.; Aguado, J.M.; Arikan-Akdagli, S.; Denning, D.W.; Groll, A.H.; Lagrou, K.; Lass-Flörl, C.; Lewis, R.E.; Munoz, P.; Verweij, P.E.; et al. Diagnosis and management of Aspergillus diseases: Executive summary of the 2017 ESCMID-ECMM-ERS guideline. Clin. Microbiol. Infect. 2018, 24 (Suppl. S1), e1-e38. [CrossRef] [PubMed]

80. De Pauw, B.; Walsh, T.J.; Donnelly, J.P.; Stevens, D.A.; Edwards, J.E.; Calandra, T.; Pappas, P.G.; Maertens, J.; Lortholary, O.; Kauffman, C.A.; et al. Revised definitions of invasive fungal disease from the European Organization for Research and Treatment of Cancer/Invasive Fungal Infections Cooperative Group and the National Institute of Allergy and Infectious Diseases Mycoses Study Group (EORTC/MSG) Consensus Group. Clin. Infect. Dis. 2008, 46, 1813-1821. [CrossRef] [PubMed] 